\title{
Students' Perception of Cell Phones Effect on their Academic Performance: A Latvian and a Middle Eastern University
}

\section{Cases}

\author{
Bashar Zogheib ${ }^{1} \cdot$ Linda Daniela ${ }^{2}$ (D)
}

Accepted: 9 April 2021 / Published online: 15 April 2021

(c) The Author(s), under exclusive licence to Springer Nature B.V. 2021

\begin{abstract}
This study is unique in its attempt to combine the Technology Acceptance Model (TAM) with external variables and the Information System Continuance Theory, in the context of mobile learning. It extends TAM with the external variables perceived mobility and perceived enjoyment. Mainly, students' perception of cell phones effect on their academic performance is investigated. The study was conducted at two different universities-in Europe and the Middle East. Cell phone usage is analyzed from the perspective of mobile learning. The data in this study were collected from 103 students from the University of Latvia and 106 students from a Middle Eastern private American University. This study shows that there is no significant difference on how the two groups perceive the use of cell phone and their opinion of its impact on their academic performance. The obtained results are in line with the theoretical model. They show the influence of perceived enjoyment and perceived usefulness on students' attitudes towards using cell phones. Data shows that there is a positive relationship between cell phone usage and students' perception of its effect on their academic performance. This study reveals several interesting findings, and it is believed that this research offers the educators and administrators further insight in analysing the current effect of cell phones on students' academic performance and the possibility of adopting mobile learning as one of the technological tools which supports technology enhanced learning.
\end{abstract}

Keywords TAM $\cdot$ Information system continuance theory $\cdot$ Academic performance $\cdot$ Cell phones $\cdot$ Mobile learning/m-learning $\cdot$ Educators

Linda Daniela

linda.daniela@lu.lv

American University of Kuwait, Salmiya, Kuwait

2 University of Latvia, Imantas 7th line, 1, Riga 1083, Latvia 


\section{Introduction}

The access to information along with possibilities provided by technologies are becoming wider every moment and they support the prediction of Moore (1965) who said that price drop of different technological solutions correlates with the increase use of them. The development of the World Wide Web (WWW) changed the way how information can be accessed, how people share information, how information can be used for different purposes and it also influenced the landscape of education and the concept of learning anytime and anywhere was introduced. The year 2007 was a new milestone when Apple, a technology company, introduced the smartphone to the world, and smart solutions gradually became available to everyone, moving from an entertainment object to a tool that can also be used for learning purposes. The free flow of information has become commonplace practice and world-wide pandemics caused by Covid-19 has shown that the technology is not only used to disrupt the learning process and to switch away the attention from the tasks which require cognitive load but also to create new innovative solutions for the provision of various services and ensuring learning.

However, not all educators are enthusiastic about the opportunities offered by technology, as the educational environment is relatively conservative, believing that technology fascination only distracts learners and this opinion is based on OECD data (2019), which concludes that technology use does not improve learning outcomes. Often the problem is that research measures the dimension of knowledge growth by paying less attention to other dimensions of knowledge, such as the dimension of access to knowledge (Daniela, 2020), which is important given the changed educational landscape, where access itself comes at the forefront and mobile technology can be perceived as knowledge transmitters which is even more important in time when almost all education is switched to remote mode where access to knowledge is provided through different media including cell phones (Stockwell, 2010). There is a relatively large amount of research that concludes that the use of mobile technology improves learners' attitudes towards the learning process (Jabbour, 2014) and thus has a positive effect on perceived usefulness.

In 1989, Davis defined the Technology Acceptance Model (TAM), which has been analyzed in research from different perspectives. He hypothesized that the attitude of a user toward the system was a major determinant of whether the user will use or reject the system (1989) which later was removed from his concept but from an educational perspective attitude is a powerful agent in formation of perceived usefulness. Later on Venkatesh and Davis (2000) proposed an extended model named TAM 2, where the variables that influence the perceived usefulness were added: (a) subjective norm: the influence of others on the user's decision to use or not to use the technology; (b) image: the desire of the user to maintain a favorable standing among others; (c) job relevance: the degree to which the technology was applicable; (d) output quality: the extent to which the technology adequately performed the required tasks; and (e) result demonstrability: the production of tangible results. Venkatesh and Bala (2008) expanded TAM2 and included there individual difference, system features, social influence (SI), and facilitating conditions as the determinants of perceived usefulness and perceived ease of use. They divided variables in two groups-The subjective norms and images in TAM2 belong to SI, while job relevance, output quality, and result demonstrability belong to the sub-dimension of system features and these variables affect perceived usefulness.

Even though both Davis himself and other researchers have made adaptations to this model, it is one of the models used to analyze the use of technology. EBSCO database 
shows that there are 197 articles that include the key words "Technology Acceptance Model" in the titles. Using the same keywords in the Web of Science database, 672 entries were found, and Scopus found 1009 entries, corresponding to the specified parameters. This confirms that this model is in the focus of attention of researchers in various fields of science and interest in it is not diminishing, even though there are also criticisms about the applicability of this model where authors believe that TAM should be integrated in a broader context including variables of human and social change processes (Legris et al, 2003).

In the context of this article, the use of cell phones is analyzed from a mobile learning perspective through TAM variables to find out which of variables are working well and which ones are not, as there are researches where TAM was empirically proven successful in predicting about $40 \%$ of a system's use (Hu et al., 1999; Legris et al., 2003). Barreh, Kadar A., \& Abas ( 2013) conducted a literature review of mobile learning approaches and concluded that there are four approaches for defining mobile learning: mobile devices, learners and learning process, learning and combination of different components, and a combination of these three approaches. Mobile learning is defined as learning using mobile devices with wireless connectivity such as mobile phones, cell phones, tablets or any other handheld devices that offer learners the opportunity to enhance their learning experience anywhere and at any time, the possibility of adapting content to every user according to their needs and expectations (Derveni, \& Dagdilelis, 2020; Abramson, Dawson, Stevens, 2015, Ally \& Prieto-Blázquez, 2014; Bachmair et al., 2010; Lowenthal, 2010). Mobile learning is not about the devices but about the people who use these devices to access the information and services, to share the knowledge, to find the answers to the questions arising and preference to mobile devices because of their flexibility (Stockwell, 2010).

Here we come back to TAM where perceived usefulness, perceived ease of use, perceived mobility and perceived enjoyment play a role in using those technologies. This study focuses on the use of mobile device - cell phone in particular, analyzing it from the TAM perspective to understand the potential of cell phones for mobile learning (Burden, Kearney, 2016, Abramson, Dawson, Stevens, 2015). This research is unique in a sense that authors aim to make a comparison of data obtained from the students from two different countries from different fields and continue the research ideas started in 2015 about technology use in mathematical learning (Zogheib, 2015). The aims of this study are twofold: first test students' perception of cell phones effect on their academic performance which will serve as an indicator for IS success (DeLone, McLean, 1992; 2003). Second, find out if there are any cultural differences in students' perceptions on use of cell phones thus showing whether or not there are differences among students from different cultural background and field of science.

TAM and the Information System Continuance Theory were used in the context of education. In this paper, they were combined in the context of mobile learning by using variety of external variables. The existing research shows that the effect of mobile learning usage in education is debatable and some researchers reported that mobility problems are holding some institutions back from implementing mobile learning. In this study, it was clear that the sample of students in Europe and the Middle East have intention to utilize cell phones to increase their academic/educational performance. Students in both countries confirmed that perceived enjoyment and perceived mobility value were major factors for the usefulness of cell phones in mobile learning. But students in Latvia regarded the cell phone more highly than those in the Middle East.

The paper is organized as follows: In a part of Theoretical framework there are main concepts analyzed included in the research which ends with the research construct 
model used; it is followed by the part which is devoted to the research methods, measurements and data analyses and ending with discussion and conclusion part.

\section{Theoretical Frame Work}

\subsection{Technology Acceptance Model (TAM) with External Variables}

Technology Acceptance Model developed by Davis (1986, 1989) is one of the most popular concepts in technology acceptance research where various researchers have analysed the factors which influence the intention to use technology and technological solutions for various purposes. It's perceived understandability and simplicity (King \& He, 2006) affected users' willingness to use technology in education (Teo, 2012) and it is believed that this model is one of the most widely used models for the research on the use of technology in educational settings (Kılıç, 2014).

The original model of TAM will be enhanced by using external variables (Liu, Chen, et al., 2010; Liu, Han, et al., 2010) becauseadditional factors should be included to extend the constructs of TAM. These factors depend mainly on the technology used, main users and context (Legris et al, 2003; Moon \& Kim, 2001). External variables that play an important role in the technology usage are related to individual differences (Wang et al., 2003) and sometimes believed that there are cultural differences which also can play a role as external varible (Fernández Robin et al., 2014). There is a strong relationship between individual differences and technology acceptance (Venkatesh, 2000). Although there are shortcomings identified by Marangunić and Granić (2015) in this model they also concluded that the model has two distinct beliefs-perceived usefulness and perceived ease of use, that were sufficient enough to predict the attitude of a user toward the use of a system because perceived enjoyment has a positive impact on perceived usefulness and plays an important role in users' technology acceptance (Wu \& Gao, 2011).

In this study perceived mobility value and perceived enjoyment are used as external variables in TAM to analyze students' perception of using cell phones as authors analyse TAM through the perspective of mobile learning.

From Information systems continuance theory perspective developed by Bhattacherjee (2001) which is focusing on the user's continuous usage rather than acceptance issues, it is important to understand the factors influencing use of different technologies (in this paper use of cell phones is in focus). This theory has a relationship with expectation confirmation theory (Oliver, 1980), which suggests that satisfaction has a major role in individuals' repeated-intention desire. These suggestions are in line with ideas of Davis that perceived enjoyment plays an important role in intention to use technologies. Yu, Yu, \& Yu ( 2012) have found a strong positive relationship between satisfaction with continuance intention which shows the role of satisfaction in forming positive attitude to continuous use of ICT. There are authors who believe that there is a narrow line which splits continuous use for job performance and repeated intention desire and technology addiction which can significantly influence individuals' personal, work, and social environment (Xu, Turel, \& Yuan, 2012). The result of this repeated behaviour depends on the users' attitude, intended purpose, that is, academic, professional, or simply leisure. 


\section{Research Model and Hypotheses Development}

Figure S1 represents the model that is being tested in this work. The endogenous constructs, perceived ease of use, perceived usefulness and attitude are influenced by the effect of the exogenous constructs perceived mobility and perceived enjoyment. Perceived usefulness plays the role of exogenous variables also when it has direct effect on attitude which in turn is considered as exogenous construct because it affects behavioral intention. Academic satisfaction performance is considered as endogenous variable because it is directly affected by the behavioral intention. The validity of the measurement is represented in the arrows that starts at the latent variable and ends at its corresponding indicators.

\subsection{Perceived Usefulness}

Davis defined perceived usefulness as the extent to which a person believes that using a particular system will enhance his or her work performance (Davis, 1986, 1989).

From extended TAM2 (Venkatesh \& Bala, 2008) where are included individual differences, system features, social influence (SI), and facilitating conditions as the determinants of perceived usefulness and perceived ease of use it is found that all these variables affect perceived usefulness which in turn is a significant predictor of learning outcomes (Zhai and Shi, 2020) as the net generation wishes that devices are easy to use to be perceived as useful (Sheppard and Vibert, 2019). According to Subramanian (1994), Fu et al. (2006) and Norazah et al. (2008), perceived usefulness and attitude toward usage behaviour are highly correlated. Therefore, the following hypotheses will be tested:

Hypotheses 1 The attitude towards using cell phones is significantly being affected by perceived usefulness.

\subsection{Perceived Ease of Use (PEU)}

The term was coined by Rogers in 1962 who said the PEU is associated with the simplicity of how users perceive the understanding and usage of a new innovation (Rogers, 1962, 1983). The attitude toward the use of TAM is also determined by the PEU. According to Davis $(1986,1989$, p. 320), (PEU) is "the degree to which a person believes that engaging in online transactions would be free of effort." The literature of the e-learning reveals that PEU is a major significant variable (e.g., Lee et al., 2005; Liu, Chen, et al., 2010; Liu, Han, et al., 2010; Park, 2009; Selim, 2003). Other studies have also offered support to the direct influence of perceived ease of use on perceived usefulness (Sheppard and Vibert, 2019). According to the following work (e.g., Teo, 2009; Teo, Teo, 2011a; Huang \& Lin 2007), PU is directly being affected by PEU. Therefore, the following hypotheses will be tested:

Hypotheses 2 Perceived usefulness of cell phones is directly being affected by perceived ease of use. 


\subsection{Attitude}

A technology user will have a positive attitude towards adopting a specific technology if the evaluation of such a technology tends to be positive. According to (Suki \& Ramayah, 2010), attitude plays the role of a mediator between PU and perceived intention to use such a technology and it is also correlates with IS success model (DeLone and McLean, 1992; 2003). Self-efficacy also is indicated as an important aspect in forming attitude (Nordlöf et al., 2019) but there are no differences in age in forming attitude to technologies (Staddon, 2020). Many researchers such as (Hu et al., 1999; Venkatesh and Davis, 1996, 2000) claimed that intention is affected by PU. Therefore, to investigate this effect by considering students' attitudes, this study hypothesizes that:

Hypotheses 3 Behavioral intention towards using cell phones is significantly being affected by attitude.

\subsection{Perceived Enjoyment (PE)}

According to Davis et al. (1989, 1992), perceived enjoyment is determined by user's enjoyment of using technology, regardless of any technical glitches. This research considers perceived enjoyment as a construct that measures how students react to the use of cell as an enjoyable tool. Enjoyment found to be an important factor that affects users' attitudes and behaviors as it is not only enjoyable but also stimulates curiosity and arouses imagination and personal innovativeness are the decisive factors for students to accept M-learning (Wu, Tam, Fang, Wu et al., 2020; Bedué, (2020) ; Igbaria et al., 1995; Teo \& Lim, 1997; Venkatesh, 2000; Childers et al., 2001; Moon \& Kim, 2001; Wexler, 2001; Mun and Hwang, 2003; van der Heijden, 2003; Yu et al., 2005; Keller, 2010; Lee et al 2017). Batra and Ray (1986) found the correlation between perceived enjoyment as an intrinsic motivation and perceived usefulness. Keller (2010) in his ARCS motivation model found that the first elements that affect the learning motivation are "capturing interest," "stimulating inquiry," and "maintaining attention". These parameters resonate to some extent with "perceived usefulness", where technologies are perceived from a usefulness perspective, which can be both interesting and informative, and from perceived ease of use, where the technology user wants the material offered to be easy to use (DeLone and McLean, 1992; 2003). Previous research also tested the effects of perceived enjoyment on perceived ease of use (Mun \& Hwang, 2003; Venkatesh, 2000; Venkatesh et al., 2002). According to Venkatesh (2000), users' technology adoption is indirectly being affected by perceived enjoyment that is considered the most important drivers behind users' intention to use technology (Qin et al., 2018). Thus, to study how perceived enjoyment affects perceived ease of use, and attitude towards using cell phones, this work tests the following:

Hypotheses 4 Perceived enjoyment has a significant effect on perceived ease of use of cell phones,

Hypotheses 5 Perceived enjoyment has a significant effect on students' attitude towards cell phones, 


\subsection{Perceived Mobility Value (PMV)}

According to (Huang et al., 2007), perceived mobility is defined as the awareness of the mobility value of mobile services and systems. It is also defined as the ability of users to receive and transmit information (Anckar and D'Incau, 2002; Coursaris et al., 2003; Hill \& Roldan, 2005; Ting, 2005). According to (Seppälä, \& Alamäki, 2003), convenience, expediency and immediacy are the three elements that forms the mobility that provides users with information via mobile devices at their convenient times. Individuals who use mobiles consider simplicity and availability of mobiles as the main factors behind the implementation of mobile learning or M-learning (Hill \& Roldan, 2005; Qashou, 2021; Ting, 2005). Therefore, the perceived mobility value is a main factor of individual differences affecting users' behaviors because it aids the student by providing ubiquitous access to both the online and hybrid classroom (Abramson, Dawson, Stevens, 2015). In certain cases, high levels of engagement and finishing tasks require adopting mobile technology (Anckar and D'Incau, 2002, p. 48). Therefore, M-learning is related to the appreciation of mobility and have a strong perception of its usefulness. This implies, perceived mobility value affects the perceived usefulness of mobile learning (Park and Kim, Huang et al., 2007; 2013). To investigate this relation, this study tests the following hypothesis:

Hypotheses 6 Perceived mobile value has a significant effect on the perceived usefulness to use cell phones,

\subsection{Behavioral Intention and Academic Performance}

According to ideas of Ajzen and Fishbein (1980) later developed by Ajzen (1991, 2011), behavioral intention is the user's readiness to continue behaving in a particular way. From technological perspective, it is to use a particular technology that directly affects actual usage. Statista (2017) claims that smartphone users in the United States has significantly increased since 2010 . Cell phones are used by students as a source of learning and sharing information. They also use social media such as Facebook and Twitter for this purpose. Students can benefit from using their cell phones by sharing files and documents and any learning material. Recent research found a positive relationship between mobile usage and students' academic performance (Alalwan et al., 2019; AlRahmi et al., 2018; Cao et al., 2013; Gikas \& Grant, 2013; Hossain et al., 2019; Junco $\&$ Cotten, 2012). Academic performance is the result of an educational course where any learner has attained their educational goal (MacGeorge et al., 2008). Based on these facts, the following hypothesis is proposed:

Hypotheses 7 Behavioral intention has a significant effect on how students perceive the effect of using cell phones on their academic performance, 


\section{Method}

\subsection{Study Context and Participants}

The study was caried out in two different countries: one European country (Latvia) and one Middle Eastern country (Kuwait), in two different higher educational institutions. In Latvia, it was the biggest public university but in Kuwait it was a private higher educational (HE) institution.

The sample in this study consisted of two groups: one group of 103 students from a public university in Latvia. The researchers used the principles of nonprobability sampling, in particular convenience sampling. Students involved in this study from University of Latvia mostly represented different subbranches of educational sciences (teachers of different subjects, preschool teachers, social pedagogues, special education teachers) and they were from different educational levels-bachelors, masters and doctors. The particular group of students were formed because one of the authors teaches educational sciences in this University. Participation of students in this study was voluntary and they were invited to fill in the questionnaire by sharing the link to the questionnaire developed in Google forms. The questionnaire was anonymos and it ensured that students could freely express their opinion. Altogether the link to the questionnaire was shared with 187 students but 103 students provided their opinion. The other group consisted of 106 students from a Middle Eastern private American University enrolled in undergraduate math classes. The students were registered in the university in different undergraduate math courses. Those classes were taught by the same professor who is one of the authors of this paper. The high school point average was the factor that determined students' major. Participants' majors were graphic design and arts, communication, economics, finance, business, computer science, information system, electrical and computer engineering, and some were unspecified. The instructor who taught the above classes was in charge of distributing the questionnaire among students and instructed them to drop it in their department mailboxes. Participants were informed that their participation is voluntary, and it is completely independent from their grades.

The response rate was very high; 106 students out of 125 answered all questions. Students who did not participate expressed no interest in the survey.

\subsection{Measures}

Multiple theoretical frameworks were combined in this study, the extended version of the technology acceptance model (TAM) and the information system continuance theory (ISs). TAM was created by Davis $(1986,1989)$ as shown in Figure S2 (Zogheib, et al 2015). Huang et al. (2007) has used original TAM with two external constructs: Perceived mobile value and perceived enjoyment (Figure S3). In this study, all of the above constructs were used. In addition, the academic self-perception construct was used. Academic self-perception is treated as an extension of the IS continuance model (Bhattacherjee, 2001), representing the psychology of adult students in terms of their academic-achievement intentions and responses. Academic self perception was measured by four indicators using a 7-point Likert-type scale. The indicators were as follows:

- I am confident in my scholastic abilities 
- I do well in college

- I learn new concepts quickly

- I am confident in my ability to succeed in college

The behavioural intention indicators were:

- I intend to check announcements from my cell phone frequently

- I intend to be a heavy user of cell phones.

The attitude indicators were:

- Studying through cell phone was a good idea

- Studying through cell phone was a wise idea,

- I am positive toward cell phone.

The perceived usefulness indicators were:

- Cell phone would improve my learning performance,

- Cell phones would increase my productivity in college,

- Cell phone could make it easier to study course content.

The perceived ease of use indicators were: “

- Learning how to use cell phones is easy for me,

- It is easy to become skilful at using cell phones.

The perceived enjoyment indicators were:

- Mobile-Learning would make me feel good,

- Mobile-Learning would be interesting," I would have using Mobile-Learning.

The perceived mobile value indicators were:

- I know that mobile devices are the mediums for Mobile-learning,

- It is convenient to access Mobile learning anywhere at any time,

- Mobility makes it possible to get the real-time data,"

- Mobility is an outstanding advantage of Mobile learning.

The validity of the measurement is represented in the arrows that starts at the latent variable and ends at its corresponding indicators.

The questionnaire was prepared in English and then translated in Latvian. To ensure that all items are correctly translated and have the same meaning, it was asked for a colleague who was not involved in the research to translate all the items back in English. Few of items were corrected to provide the cleared meaning. The questionnaire filled in by students in both countries was identical but students in Latvia filled in their answers in Latvian and Google forms were used to collect answers and students in Middle East provided their answers in English using paper form of the questionnaire. After the answers were collected all the data was summarized to allow researchers to analyze all the data together and make comparison between research groups. 
All the respondents were informed about the use of research data and the statement "By filling this questionnaire you agree that the information provided will be anonymously used in the research. You can stop filling the form if you feel that you do not wish to answer any of questions". All the ethical considerations are taken in mind to ensure data privacy.

\subsection{Data Analysis}

Smart-PLS 3.2.9 that is variance-based software was used to estimate the structural equation models. Other researchers use also different software that are covariance based. LISREL and AMOS are among these available software. Smart-PLS was used in this study because it implements no restriction on the distribution of the data (Cassel et al., 1999). Also, a chosen sample size should be 10 times the size of the largest numbers of indicators.

In the model used in this study all indicators are reflective because they are effects of the latent variables (Bollen \& Lennox, 1991).

Tables S1 \& S2 provide the information on student gender and student age respectively. Latvian students are all undergraduate students from professional qualification degree as teachers' level (bachelors level), masters or doctorate degree level studies while students in the American university are all undergraduate students.

Composite reliability, convergent validity and discriminant validity are the important elements that assess a measurement model (Barclay et al, 1995). The reliability based on the inter correlations of the indicator variables of a specific construct is measured by the composite reliability. According to (Nunally and Bernstein, 1994), the indicators will be measuring same information if the values of the composite reliability exceed 0.95. The reliability for all constructs in the model ranged between 0.916 and 0.948 as shown in Table S3. The positive correlation between an indicator and the other indicators of a construct is measured by the Convergent validity. The average variance extracted measure (AVE) is used to measure the validity. Its value should be more than 0.5 . Table S4 shows that all the validity values are between 0.765 and 0.888 . To test if a latent variable is different from another latent variable discriminant validity should be used. Fornell-Larcker criterion (Fornell \& Larcker, 1981) is one of the ways that can be used to assess discriminant validity. It is required that correlation of a specific construct with all other constructs should be lower than the square root of the AVE of that specific construct. Tables S5 \& S6 show that the square root of AVE at the diagonals are higher than those located on their rows and columns.

According to Chin (1998), the significance of the t test should be based on conducting a bootstrapping of 500 subsamples. The results of the hypothesis testing and the path coefficient are shown in Tables S7 \& S8. Seven hypotheses were tested, most hypotheses were significant at the 0.000 and the rest at a lower significance level. Table S9 shows a t-value of 8.04 indicating that there is no significant difference in the perspective of students in the University of Latvia and the American University of Kuwait regarding the value of using cell phone on their academic performance. Academic self-perception's four indicators were used to test the difference using the sum of the four indicators as the dependent measure and the region (Latvia and Middle East) of the subjects as the independent measure. The results show that the means reveals that both groups had mean values above 5.00 on this scale. 


\section{Discussion and Conclusion}

This paper investigated students' opinion on how cell phone usage affects their academic performance using the combination of TAM along with external variables and the IS continuous theory. These findings add to the existing results and debate about students' cell phone usage. Some results show that increased use may have adverse impact on academic performance (Lepp et al., 2014) but the results of this research do not show negative correlation between the use of cell phones and academic performance. This study indicates the necessity to support the development of different forms of mobile learning as cell phones can be used as a knowledge transmitters.

Perceived ease of use is defined as "the degree to which a person believes that engaging in online transactions would be free of effort." For students, this means students' perceived ability to handle using cell phone in their classes. Perceived ease of use affects perceived usefulness, this means that students find it easy to use cell phones and find that useful. Perceived usefulness affects attitude, in other words the usefulness of cell phones makes students have positive attitude towards cell phones. Attitudes towards cell phone positively affects behavioral intention which means that students have intention to utilize cell phones more in their academic activities. Perceived mobility value allows users to access information anywhere at any time via mobile devices (Huang et al., 2007). In this research, students understand that perceived mobility is an advantage for using cell phones in the learning process. The results obtained show that mobility was related to usefulness in terms of increased performance offered by the cell phones. This is in line with what other researchers found, for example Nordlöf et al. (2019) and Mallat, et al. ( 2006).

Perceived enjoyment affects perceived ease of use, that is students enjoy using cell phones and their enjoyment makes it easy to use cell phones. Perceived mobility affects perceived usefulness and behavioral intention could positively affect academic performance; this indicates that students have intention to utilize cell phones to increase academic/educational performance. The reported results agree with what is found in literature and can be explained based on TAM and the IS continuance theory (Adams, et al., 1992; Bhattacherjee, 2001; Lee, et al 2005; Saadé et al., 2007; Park, 2009; Huang, et al., 2007; Hossain, et al 2019; Venkatesh \& Davis, 2000).

The border high value for some of the constructs is considered acceptable when it is compared to what was reported in the literature. For example (Saroia \& Gao, 2019) reported a value of 0.94 for the construct university management support.

Ease of use and enjoyment constructs had values between 0.94 and 0.93 , respectively quite similar as was reported by (Yi \& Hwang, 2003). Perceived ease of use and attitude constructs had values between 0.93 and 0.94 , respectively as was reported by (Park, 2009) and confirms the idea of information system success model where user satisfaction depends on service quality (DeLone and McLean, 1992; 2003) in the context of this research ease of use of cell phones.

Students fully understanding of the constructs and differentiating them could probably lead to lower values of the composite reliability. It is recommended in any future work to explain clearly to the participants the difference between the constructs.

Institutions should be encouraged by the results of this work to implement more.

technological tools in the learning process of graduate and undergraduate program. Probably, students find that the use of cell phones positively affects their academic performance. Davis $(1986,1989)$ related perceived usefulness to the believe of a person on how a technological tool will make the job more enhanced. In this study the effect of the 
perceived usefulness construct on attitude was high. Probably, this is due students' perception that their interest in using cell phones might improve their academic performance. Students value the positive role that technological tools play on the personal level or on the social level of their lives. It is not only beneficial to them as students, but it will also leave a positive impression on their parents and educators, to realize that using cell phones had a positive influence on their education. The results of this study not only validate the theoretical model but also shed the light on how university graduate and undergraduate students interact and value the use of mobile learning and confirms the importance of variables measured. Students in both universities confirmed that perceived enjoyment and perceived mobility value in using cell phones in learning were major factors for its usefulness. It leads to conclusion that if students perceive cell phones as valuable tools for mobile learning there should be developed educational materials for such learning mode taking in mind not only content perspective, but also information architecture and ease of use. As it suggested by Aguayo, Eames, and Cochrane, learning through mobile applications should be authentic to the context, integrated within and across learning areas and scaffolded for a clear learning pathway (Aguayo, et al. 2020). On the other hand, difficulty in navigating the web, downloading, searching and sharing files from a small screen of a cell phone may negatively affect students' interest to use it for learning which is already analysed in previous research (Sheppard and Vibert, 2019).

The increased level of productivity provided by cell phones, one may conclude that both Latvian and Middle Eastern students viewed the cell phone as a tool that can help to improve academic performance. The results show that regardless the situation that research was carried out in two different countries and in two different higher education institutions, students answers are quite similar and it supports the idea that the use of technology depends mostly on the variables tested in this research and not on cultural difference. However, there appears to be a country difference on this regraded indicating that the students in Latvia evaluated the possibility to use the cell phone more highly as a academic performance enhancing tool and this was obvious from the higher mean of the constructs of academic performance for Latvian students.

The world-wide pandemic has shown that mobile technologies, including cell phones, can be a tool to replace the direct presence of the teacher, but there are a number of conditions for their successful use, some of which are linked to the Davis TAM variables. Not only from the availability of technology, but more from their perceived usefulness perceived ease of use, perceived mobility, but it is also important to analyze the impact of perceived usefulness in deeper details. In most cases, researchers talk about designing these technologies to facilitate learning, and Herrington, Herrington \& Mantei, J. ( 2009) developed 11 design principles for mobile learning to take place. Also education must take advantage of mobile technologies to deliver the knowledge anywhere and anytime (López Cruz \& Gutierrez, Cortes, 2012) but it should be done taking in mind information system success model to be sure that the effect of use of technology for learning purposes is not with a negative outcome.

This confirms the need to combine the TAM variables with other perspectives when using cell phones, as perceived usefulness must be seen from the perspective of usefulness, which in the learning context means increasing knowledge, access to knowledge, accumulation of knowledge and evaluation of knowledge. From other perspective, this perceived usefulness would be different. It could be the speed of access to some services, possibility to solve problems etc. Therefore, thinking about further research on the Technology Acceptance model by analyzing cell phone usability can be analyzed from different perspectives. The perspective chosen in this article was students' views on cell phone usability 
and it was analysed from the perspective of mobile learning, but the study could be deepened by analyzing the learning benefit perspective, or other perspectives of mobile learning. It is also necessary to keep in mind that cell phones provide an opportunity to split the attention and it can influence the cognitive load (Park, 2015; Sweller et al, 1998) which is needed to learn something new.

Although this research provided interesting results, it is lacking the breadth because it was conducted to students in a private American university in the Middle East and a public university in Europe. To generalize the results obtained, the same model should be used at different universities in the Middle East and Europe, public and private. Researchers are also encouraged to extend this work to demographic characteristics, for example, age, gender, etc.

Supplementary Information The online version contains supplementary material available at https://doi. org/10.1007/s10758-021-09515-4.

\section{Declarations}

Conflict of interest There is no conflict of interest. The data collected by following all ethical guidelines. All the data is anonymized.

\section{References}

Abramson, J., Dawson, M., \& Stevens, J. (2015). An Examination of the prior use of E-learning within an extended technology acceptance model and the factors that influence the behavioral intention of users to use M-learning. SAGE Open. https://doi.org/10.1177/2158244015621114

Adams, D. A., Nelson, R. R., \& Todd, P. A. (1992). Perceived usefulness, ease of use, and usage of information technology: A replication. MIS quarterly, 35, 227-247

Ajzen, I. (2011). The theory of planned behaviour: Reactions and reflections. Taylor and Francis.

Ajzen, I., \& Fishbein, M. (1980). Understanding attitudes and predicting social behavior. Prentice Hall.

Alalwan, N., Al-Rahmi, W. M., Alfarraj, O., Alzahrani, A., Yahaya, N., \& Al-Rahmi, A. M. (2019). Integrated three theories to develop a model of factors affecting students' academic performance in higher education. IEEE Access, 7, 98725-98742

Ally, M., \& Prieto-Blázquez, J. (2014). What is the future of mobile learning in education? mobile learning applications in higher education [special section]. Revista de Universidad y Sociedad del Conocimiento (RUSC)., 11(1), 142-151

Aguayo, C., Eames, C., \& Cochrane, T. A. (2020). Framework for mixed reality free-choice. (p. 28). SelfDetermined Learning.

Al-Rahmi, W. M., Alias, N., Othman, M. S., Marin, V. I., \& Tur, G. (2018). A model of factors affecting learning performance through the use of social media in Malaysian higher education. Computers and Education, 121, 59-72

Anckar, B., \& D'incau, D. (2002). Value creation in mobile commerce: Findings from a consumer survey \{JITTA $\}$. Journal of Information Technology Theory and Application, 41(8), 356

Bachmair, B., Cook, J., \& Kress, G. R. (2010). Mobile learning: structures, agency, practices. Springer.

Barclay, D., Higgins, C., \& Thompson, R. (1995). The partial least squares (PLS) approach to causal modeling: Personal computer adoption and use as an illustration. Technology studies, 2(2), 285-309

Barreh, Kadar A., \& Abas Z. W. (2013). A Framework for Mobile Learning for Enhancing Learning in Higher Education. Malaysian Online Journal of Educational Technology, 3(3). Retrieved from www. mojet.net

Batra, R., \& Ray, M. L. (1986). Affective responses mediating acceptance of advertising. Journal of Consumer Research, 13(2), 234-249

Bedué, P. (2020). Just fun and games? Utilitarian and hedonic chatbot perceptions and their role for continuance intentions. In W. Abramowicz \& G. Klein (Eds.), Business information systems BIS 2020. lecture notes in business information processing vol 389.Springer.

Bhattacherjee, A. (2001). Understanding information systems continuance. An Expectation Confirmation Model, MIS Quarterly, 25(3), 351-370 
Bollen, K., \& Lennox, R. (1991). Conventional wisdom on measurement: A structural equation perspective. Psychological bulletin, 110(2), 305

Burden, K., \& Kearney, M. (2016). Conceptualising authentic mobile learning. In D. Churchill, J. Lu, K. F. T. Chiu, \& B. Fox (Eds.), Mobile learning design: theories and application. (pp. 27-42). Springer.

Cao, Y., Ajjan, H., \& Hong, P. (2013). Using social media applications for educational outcomes in college teaching: A structural equation analysis. British Journal of Educational Technology, 44(4), 581-593

Cassel, C., Hackl, P., \& Westlund, A. H. (1999). Robustness of partial least-squares method for estimating latent variable quality structures. Journal of applied statistics, 26(4), 435-446

Childers, T. L., Carr, C. L., Peck, J., \& Carson, S. (2001). Hedonic and utilitarian motivations for online retail shopping behavior. Journal of retailing, 77(4), 511-535

Chin, W. W. (1998). The partial least squares approach to structural equation modeling. Modern methods for business research, 295(2), 295-336

Coursaris, C., Hassanein, K., \& Head, M. (2003). M-commerce in Canada: An interaction framework for wireless privacy. Canadian Journal of Administrative Sciences/Revue Canadienne des Sciences de l'Administration, 20(1), 54-73

Daniela, L. (2020) The Concept of Smart Pedagogy for Learning in the Digital World, in Epistemological Approaches to Digital Learning in Educational Contexts, ed. L.Daniela, Taylor\&Francis, (pp. 1-16) ISBN 9780367333799

Davis, F.D. (1986), "A technology acceptance model for empirically testing new end-user information systems: theory and results”, doctoral dissertation, MIT Sloan School of Management, Cambridge, MA.

Davis, F. D. (1989). Perceived usefulness, perceived ease of use, and user acceptance of information technology. MIS Quarterly, 13(3), 319-339

Davis, F. D., Bagozzi, R. P., \& Warshaw, P. R. (1989). User acceptance of computer technology: A comparison of two theoretical models. Management Science, 35(8), 982-1003

Davis, F. D., Bagozzi, R. P., \& Warshaw, P. R. (1992). Extrinsic and intrinsic motivation to use computers in the workplace 1. Journal of applied social psychology, 22(14), 1111-1132

DeLone, W. H., \& McLean, E. R. (1992). Information systems success: The quest for the dependent variable. Information Systems Research., 3(1), 60-95

DeLone, W. H., \& McLean, E. R. (2003). The DeLone and McLean model of information systems success: A ten-year update. Journal of Management Information Systems., 19(4), 9-30

Derveni, K., \& Dagdilelis, V. (2020). Perceptions of primary education teachers on mobile learning: An approach in Greek and Latvian teachers. International Journal of Smart Education and Urban Society (IJSEUS), 11(3), 52-68

Fernández, R. C., McCoy, S., Yáñez, S. L., \& Yáñez, M. D. (2014). Technology acceptance model: Worried about the cultural influence? In F. F. H. Nah (Ed.), HCI in business HCIB lecture notes in computer science.Cham: Springer.

Fornell, C., \& Larcker, D. F. (1981). Evaluating structural equation models with unobservable variables and measurement error. Journal of marketing research, 18, 39-50

Fu, J. R., Farn, C. K., \& Chao, W. P. (2006). Acceptance of electronic tax filing: A study of taxpayer intentions. Information and Management, 43, 109-126

Gikas, J., \& Grant, M. M. (2013). Mobile computing devices in higher education: Student perspectives on learning with cellphones, smartphones and social media. The Internet and Higher Education, 19, $18-26$

Herrington, A., Herrington, J., \& Mantei, J. (2009). Design principles for mobile learning. In J. Herrington, A. Herrington, J. Mantei, I. Olney, \& B. Ferry (Eds.), New Technologies, New Pedagogies: Mobile Learning in Higher Education (pp. 129-138). Wollongong: University of Wollongong. Retrieved from http://ro.uow.edu.au/

Hill, T. R., \& Roldan, M. (2005). Toward third generation threaded discussions for mobile learning: Opportunities and challenges for ubiquitous collaborative environments. Information Systems Frontiers, 7(1), 55-70

Hossain, S. F. A., Nurunnabi, M., Hussain, K., Saha, S. K., \& Wang, S. (2019). Effects of variety-seeking intention by mobile phone usage on university students' academic performance. Cogent Education, $6(1), 1574692$

Hu, P. J., Chau, P. Y. K., Liu Sheng, O. R., \& Yan Tam, K. (1999). Examining the technology acceptance model using physician acceptance of telemedicine technology. Journal of Management Information Systems, 16(2), 91-112

Huang, J. H., Lin, Y. R., \& Chuang, S. T. (2007). Elucidating user behavior of mobile learning. The electronic library, 25(5), 585-598

Igbaria, M., Meredith, G., \& Smith, D. C. (1995). Career orientations of information systems employees in South Africa. The Journal of Strategic Information Systems, 4(4), 319-340 
Jabbour, K. K. (2014). An analysis of the effect of mobile learning on lebanese higher education. Informatics in Education, 13, 1-15

Junco, R., \& Cotten, S. R. (2012). No A 4 U: The relationship between multitasking and academic performance. Computers and Education, 59(2), 505-514

Keller, J. M. (2010). Motivational design for learning and performance: The ARCS model approach. Springer.

Kiliç, E. (2014). Determining the factors of affecting the Moodle use by using TAM. The story of a university after a destructive earthquake. Hacettepe Üniversitesi Ĕ̈itim Fakültesi Dergisi, 29(1), 169-179

King, W. R., \& He, W. R. (2006). A meta-analysis of the technology acceptance model. Information and Management, 43(6), 740-755

Lee, D.-C., Lin, S.-H., Ma, H.-L., \& Wu, D.-B. (2017). Use of a modified UTAUT model to investigate the perspectives of internet access device users. International Journal of Human-Computer Interaction, 33(7), 549-564

Lee, M. K. O., Cheung, C. M. K., \& Chen, Z. (2005). Acceptance of internet-based learning medium: The role of extrinsic and intrinsic motivation. Information and Management, 42, 1095-1104

Legris, P., Ingham, J., \& Collerette, P. (2003). Why do people use information technology? A critical review of the technology acceptance model. Inf. Manag., 40, 191-204

Lepp, A., Barkley, J. E., \& Karpinski, A. C. (2014). The relationship between cell phone use, academic performance, anxiety, and satisfaction with life in college students. Computers in human behavior, 31, 343-350

Liu, I. F., Chen, M. C., Sun, Y. S., Wible, D., \& Kuo, C. H. (2010a). Extending the TAM model to explore the factors that affect Intention to Use an online learning community. Computers and Education, 54(2), 600-610

Liu, Y., Han, S., \& Li, H. (2010b). Understanding the factors driving m-learning adoption: A literature review. Campus-Wide Information Systems, 27, 210-226

López Cruz, C. S. \& Gutierrez Cortes, F. I. (2012). Mobility in Learning: Interdisciplinary Experiences. In Proceedings of World Conference on E-Learning in Corporate, Government, Healthcare, and Higher Education 2012 (pp. 1845-1849). Chesapeake, VA: AACE.

Lowenthal, J. N. (2010). Using mobile learning: determinates impacting behavioral intention. American Journal of Distance Education, 24(4), 195-206

MacGeorge, E. L., Homan, S. R., Dunning, J. B., Elmore, D., Bodie, G. D., Evans, E., \& Geddes, B. (2008). Student evaluation of audience response technology in large lecture classes. Educational Technology Research and Development, 56(2), 125-145

Mallat, N., Rossi, M., Tuunainen, V. K., \& Oorni, A. (2006, January). The impact of use situation and mobility on the acceptance of mobile ticketing services. In Proceedings of the 39th Annual Hawaii International Conference on System Sciences (HICSS'06) (Vol. 2, pp. 42b-42b). IEEE.

Marangunić, N., \& Granić, A. (2015). Technology acceptance model: A literature review from 1986 to 2013. Universal Access in the Information Society, 14, 81-95

Mun, Y. Y., \& Hwang, Y. (2003). Predicting the use of web-based information systems: Self-efficacy, enjoyment, learning goal orientation, and the technology acceptance model. International Journal of human-computer studies, 59(4), 431-449

Moon, J. W., \& Kim, Y. G. (2001). Extending the TAM for a world-wide-web context. Information and Management, 38(4), 217-230

Moore, G. (1965). Cramming more components onto integrated circuits. Electronics, 38(8), 114-117. Retrieved from https://newsroom.intel.com/wp-content/uploads/ sites/11/2018/05/moores-law-electronics.pdf

Norazah, M. S., Ramayah, T., \& Norbayah, M. S. (2008). Internet shopping acceptance: Examining the influence of intrinsic versus extrinsic motivations. Direct Marketing: An International Journal, 2(2), 97-110

Nordlöf, C., Hallström, J., \& Höst, G. E. (2019). Self-efficacy or context dependency?: Exploring teachers' perceptions of and attitudes towards technology education. International Journal of Technology and Design Education, 29, 123-141

Nunnally, J. C., \& Bernstein, I. H. (1994). The assessment of reliability. Psychometric theory, 3, 248-292

OECD. (2019). ICT for teaching. In TALIS 2018 Results (Volume I): Teachers and SchoolLeaders as Lifelong Learners. Paris: OECD Publishing. doi:https://doi.org/10.1787/3ddd8e5a-en

Oliver, R. L. (1980). A cognitive model of the antecedents and consequences of satisfaction decisions. Journal of marketing research, 17(4), 460-469

Park, S. Y. (2009). An analysis of the Technology Acceptance Model in understanding university students' behavioral intention to use e-Learning. Educational Technology and Society, 12(3), 150-162 
Park, E., \& Kim, K. J. (2013). User acceptance of long-term evolution (LTE) services. Program: An application of extended technology acceptance model". Program, 47(2), 188-205

Park, S. (2015). The effects of social cue principles on cognitive load, situational interest, motivation, and achievement in pedagogical agent multimedia learning. Educational Technology and Society, 18(4), 211-229

Qashou, A. (2021). Influencing factors in M-learning adoption in higher education. Education and Information Technologies, 26, 1755-1785

Qin, L., Kim, Y., \& Tan, X. (2018). Understanding the intention of using mobile social networking apps across cultures. International Journal of Human-Computer Interaction, 34(12), 1183-1193

Rogers, E. M. (1962). Diffusion of innovations (1. (st). Free Press.

Rogers, E. M. (1983). Diffusion of innovations (4. (th). The Free Press.

Saadé, R., Nebebe, F., \& Tan, W. (2007). Viability of the "Technology Acceptance Model" in multimedia learning environments: A comparative study. Interdisciplinary Journal of E-Learning and Learning Objects, 3(1), 175-184. Retrieved from http://www.ijello.org/Volume3/IJKLOv3p175184Saade393.pdf

Saroia, A. I., \& Gao, S. (2019). Investigating university students' intention to use mobile learning management systems in Sweden. Innovations in Education and Teaching International, 56(5), 569-580

Selim, H. M. (2003). An empirical investigation of student acceptance of course websites. Computers and Education, 40(4), 343-360

Seppälä, P., \& Alamäki, H. (2003). Mobile learning in teacher training. Journal of computer assisted learning, 19(3), 330-335

Sheppard, M., \& Vibert, C. (2019). Re-examining the relationship between ease of use and usefulness for the net generation. Education and Information Technologies, 24, 3205-3218

Staddon, R. V. (2020). Bringing technology to the mature classroom: age differences in use and attitudes. International Journal of Educational Technology in Higher Education, 17, 11

Statista. (2017). Number of smartphone users in the U.S. 2010-2022. Statista. Retrieved from: https:// www. statista.com/statistics/201182/forecast-of- smartphone-users-in-the-us

Stockwell, G. (2010). Using mobile phones for vocabulary activities: Examining the effect of the platform. Language Learning \& Technology, 14(2), 95-110. Retrieved from http://lit.msu.edu/vol14num2/stock well.pdf.

Subramanian, G. H. (1994). A replication of perceived usefulness and perceived ease of use measurement. Decision Sciences, 25(5-6), 863-874

Suki, N. M., \& Ramayah, T. (2010). User acceptance of the e-government services in Malaysia: structural equation modelling approach. Interdisciplinary Journal of Information, Knowledge, and Management, 5(1), 395-413

Sweller, J., van Merrienboer, J. J. G., \& Paas, F. G. W. C. (1998). Cognitive architecture and instructional design. Educational Psychology Review., 10(3), 251-296

Teo, T. (2009). Modelling technology acceptance in education: A study of pre-service teachers. Computers and Education, 52(2), 302-312

Teo, T. (2011). Factors influencing teachers' intention to use technology: Model development and test. Computers \& Education, 57, 2432-2440

Teo, T. (2012). Examining the intention to use technology among pre-service teachers: An integration of the technology acceptance model (TAM) and theory of planned behavior (TPB). Interactive Learning Environments, 20(1), 3-18

Teo, T. S. H., \& Lim, V. K. G. (1997). Usage patterns and perceptions of the internet: The gender gap. Equal Opportunities International, 16(6/7), 1-8

Ting, R. Y. L. (2005, July). Mobile learning: Current trend and future challenges. In Fifth IEEE International Conference on Advanced Learning Technologies (ICALT'05) (pp. 603-607). IEEE.

Van der Heijden, H., Verhagen, T., \& Creemers, M. (2003). Understanding online purchase intentions: Contributions from technology and trust perspectives. European Journal of Information Systems, $12(1), 41-48$

Venkatesh, V. (2000). Determinants of perceived ease of use: Integrating control, intrinsic motivation, and emotion into the technology acceptance model. Information Systems Research, 11(4), 342-365

Venkatesh, V., \& Bala, H. (2008). Technology acceptance model 3 and a research agenda on interventions. Decision Sciences, 39(2), 273-315

Venkatesh, V., \& Davis, F. D. (1996). A model of the antecedents of perceived ease of use: development and test. Decision Sciences, 27, 451-481. https://doi.org/10.1111/j.1540-5915.1996.tb00860.x.

Venkatesh, V., \& Davis, F. D. (2000). A theoretical extension of the technology acceptance model: Four longitudinal field studies. Management Science, 46(2), 186-204 
Venkatesh, V., Speier, C., \& Morris, M. G. (2002). User acceptance enablers in individual decision making about technology: Toward an integrated model. Decision Sciences, 33(2), 297-316

Wang, Y. S., Wang, Y. M., Lin, H. H., \& Tang, T. I. (2003). Determinants of user acceptance of Internet banking: An empirical study. International Journal of Service Industry Management, 4(5), 501-519

Wexler, J. (2001). Why computer users accept new systems. MIT Sloan Management Review, 42(3), 17

Wu, X., \& Gao, Y. (2011). Applying the extended technology acceptance model to the use of clickers in student learning: Some evidence from macroeconomics classes. American Journal of Business Education, 4(7), 43-50

Wu, X., Tam, C. M., \& Fang, S. (2020). Users' behavioral intention toward M-learning in tourism english education: A case study of macao. In L. K. Lee, F. L. Wang, S. K. S. Cheung, O. Au, \& K. C. Li (Eds.), Technology in education innovations for online teaching and learning ICTE 2020.Singapore: Springer.

Xu, Z., Turel, O., \& Yuan, Y. (2012). Online game addiction among adolescents: Motivation and prevention factors. European Journal of Information Systems, 21(3), 321-340

Yi, M. Y., \& Hwang, Y. (2003). Predicting the use of web-based information systems: Self-efficacy, enjoyment, learning goal orientation, and the technology acceptance model. International Journal of Human-Computer Studies, 59(4), 431-449. https://doi.org/10.1016/S1071-5819(03)00114-9.

Yu, J., Ha, I., Choi, M., \& Rho, J. (2005). Extending the TAM for a t-commerce. Information and Management, 42(7), 965-976

Yu, C., Yu, C.-C., \& Yu, T.-F. (2012). The exploring of the perceived quality, confirmation and satisfaction on E-learning continuance intention in the context of E-learning environment. International Journal of Digital Content Technology and Its Applications, 6, 76-85

Zhai, X., \& Shi, L. (2020). Understanding how the perceived usefulness of mobile technology impacts physics learning achievement: A pedagogical perspective. Journal of Science Education and Technology, 29, 743-757

Zogheib, B., Rabaa'i, A., Zogheib, S., \& Elsaheli, A. (2015). University student perceptions of technology use in mathematics learning. Journal of Information Technology Education: Research, 14, 417-438

Publisher's Note Springer Nature remains neutral with regard to jurisdictional claims in published maps and institutional affiliations. 